\title{
An Analysis of Non-Observance Maxims in Customs Protection
}

\author{
Muhammad Fadillah, Ernie D. A. Imperiani \\ English Language and Literature Study Program \\ Universitas Pendidikan Indonesia \\ Bandung, Indonesia \\ ernie_imperiani@upi.edu
}

\begin{abstract}
The paper investigated non-observance of maxims among Indonesians and foreigners male and female passengers at Indonesian airport when the customs officers were checking the passengers. Specifically, it analyzed the types of non-observance of maxims along with the possible reasons as to why the passengers broke the maxims. This descriptive qualitative research applied the theory of Cooperative Principles by Grice (1975) to identify the maxims in a conversation between passengers and customs officers and Christoffersen's (2005) theory in analyzing the possible reasons for breaking maxims. The data were taken from a transcription video of a reality show entitled "Customs Protection" that were obtained from its Youtube channel. The findings revealed that the passengers broke the Maxim of Quantity, the Maxim of Quality, and the Maxim of Relation. Also, the passengers were flouted more on the Maxims of Quantity in the conversation. Moreover, most of the maxims were broken due to the reason to convince someone. The passengers were likely to flout the maxim of quantity to convince the customs officer with an indicator to avoid the process of customs declaration for each item that the passengers brought from overseas.
\end{abstract}

Keywords: Cooperative Principle, Customs Protection, maxims

\section{INTRODUCTION}

In general, the Cooperative Principle is a set of rules which makes a conversation effective and efficient in communication according to the required contribution. As Grice (1975) suggests that when a speaker and a hearer have a conversation, they need to be informative to show cooperation and understanding in the conversation, so the goal of the conversation can be effective and efficiently achieved. To fulfill the effectiveness of conversation, Grice (1975) states that in the maxim of quality the speaker is supposed to be truthful when giving a contribution in conversation, while the maxim of quantity suggests the speaker to be informative as required (not more or less informative). The other two maxims are; maxims of relevance, which advise the speaker to be related to the discussed topic in the conversation and maxim of manner that expects the speaker to avoid obscurity and ambiguous expression. In maxim of manner, it is also crucial for being brief and order.

However, in real life, some speakers may not obey the principles of maxims. It may be due to make a more precise meaning in the process of giving information or hiding some information. The phenomena can occur in a daily conversation where the speaker decides for being uncooperative or reject to contribute as required. In her study, Herawati (2013) argues that in some particular conditions, when people tend to reject in observing maxims, they are indicated to have another purpose of interaction. If the speaker chooses to be uncooperative intentionally or unintentionally, the speaker is assumed to have another intention or other purpose in interaction. In the phenomena of breaking the maxims, the speaker can choose between to violate, to flout, to infringe, to opt-out, or to suspend the maxims. These terms are also called as non-observance of maxims.

When people break the maxims, they are assumed to have an intention in hiding some information or another purpose in an interaction. According to Christoffersen (2005), there are some possible factors for people to break maxims. These factors are hiding the truth, creating jokes, avoiding certain topics, averting to hurt someone's feelings, saving face, creating fake truth, convincing someone, and cheering the hearer.

Some cases of non-observance maxims may also be found in the airport, especially in a conversation between passengers and customs officers in customs checking. Mostly the passengers do not provide direct answers and prefer to go around the bush when the customs officer asks them. The unclear utterance creates an obstacle for customs officers in examining passenger baggage or belonging.

One of the Indonesian TV programs which provide a condition where a passenger is having a conversation with a customs officer in the airport is Customs Protection. It is a reality show TV Program in the NET TV channel that collaborates with the Directorate General of Customs and Excise Indonesia. The show is presenting an actual event or phenomenon in securing traffic of goods, monitoring export and import activities, customs clearance, and others based on government regulation and laws that apply in Indonesia.

Several studies are deal with Customs Protection, Atmajaya (2017) investigated the influence of broadcasting Customs Protection TV program toward the image of Directorate General of Customs and Excise Indonesia, Desilvani, Hafiar, and Damayanti (2017) analyzed how drug smuggling case and the image of Indonesian Customs and Excise is framed through Customs Protection NET TV.

Both of the studies show a similar result that Customs Protection is an effective TV program that can provide a piece of information about how Indonesian Customs and Excise protecting the country from illegal and prohibited goods. It also creates a positive image for Indonesian Customs and Excise in 
the society that is a trustful and reliable institution for solving problems related to customs and excise in Indonesia.

\section{METHOD}

This research used a descriptive qualitative method to identify the data (Berg, 2006). The data for this research was in the form of transcription from a video, which was taken from Youtube, specifically from the 86 \& Customs Protection NET channel. Five (5) videos were selected for this research by focusing only on the video that takes place in Indonesian Airport, and the length of the videos ranging from six to eight minutes per video.

The data analysis involved the categorizing and classifying the maxims found in a form of a table whether it flouts, violates, opts-out infringes, or suspends the maxim by using Grice's (1975) theory about Cooperative Principle. Besides, the possible factors also investigated based on Christoffersen (2005) regarding the criteria of lying.

\section{FINDINGS AND DISCUSSION}

The findings reveal that the passengers break three out of four maxims that are proposed by Grice (1975). In terms of nonobservance of maxims, most passengers decided to break the maxims by flouting or violating it rather than to break it with the three other types. Furthermore, the possible reasons why the passengers did not provide direct answers were also identified. As a piece of additional information, the participants are Indonesian and foreign male and female passengers.

\section{A. Non-observance Maxims}

In terms of non-observance maxims, some maxims were broken by the passengers when answering the customs officers' questions. Three maxims were identified to be broken, which are; Maxims of Quality, Maxim of Quantity, and Maxim of Relation. The list of occurrences regarding non-observance maxims is presented in the following Table I.

TABLE I. FREQUENCIES OF BROKEN MAXIMS BY PASSENGE
\begin{tabular}{|l|c|c|c|}
\hline Maxim Types & Occurrences & Percentage & Rank \\
\hline Quality & 9 & $18,4 \%$ & 3 \\
\hline Quantity & 26 & $53,1 \%$ & 1 \\
\hline Relation & 14 & $28,5 \%$ & 2 \\
\hline Manner & 0 & $0 \%$ & - \\
\hline Total & 49 & $100 \%$ & - \\
\hline
\end{tabular}

From Table I above, it shows that not all of the broken principles were found in the conversation between the passenger and the customs officer. There are three types of broken maxims occurred, which are; Quality, Quantity, and Relation. From the total of 49 occurrences of broken maxims, Maxim of Quantity becomes the most frequent of broken maxims with 26 occurrences $(53,1 \%)$ The second most frequent broken maxim is Maxim of Relation with 14 occurrences $(28,5 \%)$ and the third position is Maxim of Quality, the passengers did not observe the Maxim Quality 9 times $(18,4 \%)$ in the conversation which caused by a failure of providing true information while uttering their response so the principle of truthful cannot be achieved. However, Maxim of Manner was not found or broken in the conversation.

\section{B. Types of Non-observance of Maxims}

The occurrences and percentage of non-observed maxims are shown in Table II.

TABLE II. FREQUENCIES OF NON-OBSERVANCE MAXIMS BY PASSENGERS

\begin{tabular}{|c|c|c|c|}
\hline Non-observed Maxim & Occurrences & Percentage & Rank \\
\hline Flouting Maxim of Quantity & 18 & $36,7 \%$ & 1 \\
\hline Flouting Maxim of Quality & 2 & $4,1 \%$ & 6 \\
\hline Flouting Maxim of Relation & 5 & $10,2 \%$ & 5 \\
\hline Violating Maxim of Quantity & 8 & $16,3 \%$ & 3 \\
\hline Violating Maxim of Quality & 7 & $14,3 \%$ & 4 \\
\hline Infringing Maxim of Relation & 9 & $18,4 \%$ & 2 \\
\hline Total & 49 & $100 \%$ & - \\
\hline
\end{tabular}

As can be seen in Table II there are three main types of nonobservance maxims: Flouting, Violating and Infringing. When the passengers were asked by the customs officer, they decided to flout the maxim of quantity 18 times $(36,7 \%)$ out of 49 pairs of conversation and followed by infringing the maxim of relation with 9 times $(18,4 \%)$ occurrences out of 49 pairs of conversation. Furthermore, with a slight difference of occurrence, violating the maxim of quantity occurs 8 times $(16,3 \%)$ while violating the maxim of quality occurs 7 times $(14,3 \%)$. Flouting the maxim of quality becomes the least frequent non-observance of maxims that performed by the passenger with 2 times $(4,1 \%)$ occurrences among the conversation between the passengers and customs officer.

\section{Flouting Maxim of Quantity}

The maxim of quantity suggests the speaker gives the required information, not more or less informative than required. The provided example below is an example of flouting the maxim of quantity.

\section{O1 : Ini baru ya Pak yah? \\ Is this new, sir? \\ P1 : Iya, barang murah. \\ Yes, cheap items.}

The example shows P1 breaks the maxim of quantity, specifically flouting the maxim of quantity. P1 gives more information rather than required in answering $\mathrm{O} 1$ 's question. In addition, P1 wanted to make the items are less expensive so P1 does not have to pay tax for the items that were bought from overseas.

Besides, the passenger's items were identified as expensive items from the price tag. The officer also knew the items exceeded the limit of personal use tax-free regulation, which is 500 USD per person after saw the price tag.

P1 actually can answer O1's question using yes or no answer and that is enough to fulfill the maxim of quantity. However, P1 decided to add more information for the answer and it 
considered as flouting to convince someone and particularly in this context to avoid paying tax for the items.

\section{Flouting Maxim of Quality}

The maxim of quality expects the speaker to provide truthful information or simply based on fact. This is an example where the speaker flouts the maxim of quality.

O4 : Kalau disini sih 16 jutaan, ya 17 juta lah, karena pembebasannya cuma 500 USD tuh sekitar 7 juta baru selebihnya akan dikenakan pajak.

The price here is around 16 million, or 17 million because the tax-free is 500 USD, it is around 7 million then the rest will be tax charged.

P4 : Katanya kalau lagi dipakai enggak kena.

If I wear it, it will not get charged, they said.

The illustration shows that $\mathrm{P} 4$ breaks the maxim of quality by flouting. It can be seen that $\mathrm{P} 4$ refused to be cooperative in answering O4's question. P4 indicated to avoid paying tax by claiming that if the items were worn it will not get charged for tax. This is in contrast with the fact that there is no such a rule like that. Every new expensive item that was bought from overseas will be charged with no excuse.

As mentioned before, the regulations for personal use items that were brought by each passenger is only 500 USD or 1000 USD for 1 family. In other words, if the price is over limit it will be charged for tax and the customs officer will help to handle in calculating the tax.

O4 is expecting that $\mathrm{P} 4$ can be cooperative that $\mathrm{P} 4$ understands about the regulation and pay the tax. Unfortunately, $\mathrm{P} 4$ cannot provide sufficient information for the utterance, which makes the answer implied as breaking the maxim of quality.

\section{E. Flouting Maxim of Relation}

The maxim of relation is a maxim where the speaker is supposed to contribute a relevant answer in a conversation. An illustration below is an example of how the speaker flouts the maxim of relation.

\section{O1 : Di declare sama komandan kita yah? \\ It will be declared by our chief, okay? \\ P1 : Aduh, salah saya. Di email bisa gak ya? \\ Ugh, my bad. Can I send it by email?}

The example above is an illustration of flouting in the maxim of relation where $\mathrm{P} 1$ did not provide a related answer regarding the given question by $\mathrm{O} 1$. When $\mathrm{P} 1$ was asked to meet the customs chief for declaring items P1 refused to contribute in the conversation because P1 has an intention of avoiding declare process of items with the customs chief.

O1's question is a simple yes or no question, but since P1 wanted to escape from the problem P1 choose to flout the maxim by answering an irrelevant answer by asking the officer if $\mathrm{P} 1$ can send the invoice via email.

\section{F. Violating Maxim of Quantity}

The maxim of quantity suggests the speaker to give required information, not more or less informative than required. A conversation below is an instance for violating the maxim of quantity.

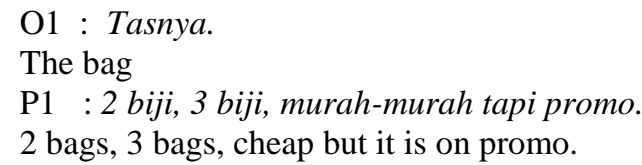

The example above shows the act of violating the maxim of quantity where P1 intentionally wants to mislead $\mathrm{O} 1$ with the answer. O1 was asking about how many items that P1 bought from overseas, but $\mathrm{P} 1$ talks too much meanwhile $\mathrm{O} 1$ knows that the price tag of the bag is still hanging on it

P1 only has to answer the quantity of the bag to fulfill the principle of quantity and provides true information to avoid violation. Besides, $\mathrm{P} 1$ wants to convince $\mathrm{O} 1$ that the bag is not expensive because it was on promo even though the price tag exists but $\mathrm{P} 1$ cannot prove it.

Besides, Virgin \& Utami (2016) claim that violation of the maxim of relevance is more frequent to occur than others. This is because in Virgin \& Utami's (2016) study the speaker is more often to violate the maxims of relevance to create a sense of joke or humor. Meanwhile, in this study, the result shows that the violation of maxim quantity is more frequently occur where the speakers many times are found did not provide the necessary information, either more or less information.

\section{G. Violating Maxim of Quality}

The maxim of quality expects the speaker to provide truthful information or simply based on fact. The example below illustrates the violation in the maxim of quality.

O2 : Ini udah sering, pak. Kalau cuma sekali, soalnya bapak kan udah rutin ya.

This is frequent, sir. If only once, but you go overseas frequently.

P2 : Saya kalau bawa baju ini baru sekali, pak.

This is my first time for bringing clothes, sir.

The illustration above is an example of the maxim of quality that was violated. In this case, $\mathrm{P} 2$ wants to persuade $\mathrm{O} 2$ that this is the first time $\mathrm{P} 2$ brings many clothes but $\mathrm{O} 2$ does not believe it because it is illogical if $\mathrm{O} 2$ brought many clothes only for their families as a souvenir from overseas.

P2's utterance is categorized as violating the maxim of quality because the provided information is not based on fact $(\mathrm{O} 2$ knows P2 go overseas frequent). Moreover, P2's answer is intended to mislead the hearer.

The example clearly shows that the speaker wants to mislead the hearer by giving false information. The speaker also did not provide an evidence to support the answer so P2 is violating the maxim of quality. 


\section{H. Infringing Maxim of Relation}

The maxim of relation is a maxim where the speaker is supposed to contribute a relevant answer in their conversation. The following illustration is an example of the infringing maxim of relation.

\section{O2 : Can you speak English? \\ Can you speak English? \\ P2 : Huh? \\ Huh?}

The example shows that $\mathrm{P} 2$ breaks the maxim of relation, specifically infringing maxim of relation. The uttered expression by $\mathrm{P} 2$ is not related to the topic that asked by $\mathrm{O} 2$. Instead of answering the question, P2 uttered with ambiguous expressions like confusion.

P2 does not contribute toward the maxim of relation. This may be caused by the nationality of $\mathrm{P} 2$, which is Japan, and P2 does not have a capability of understanding in English or Bahasa Indonesia so it makes P2 cannot answer O2's question. While $\mathrm{O} 2$ has utter the question clearly by asking if $\mathrm{P} 2$ can speak English so it can help the process of checking easier for $\mathrm{O} 2$.

As Grice (1975) mentioned, infringing is one of the nonobservance maxims that can occur among foreigners due to lack of knowledge to the language and example of P2 who is originally from Japan represents it.

\section{The Possible Reasons for Breaking the Maxims}

According to Christoffersen (2005), there are eight (8) types of possible reasons why people are breaking the maxims. From the findings, there are some reasons as to why the passengers break the maxims; which are, avoiding certain topics, saving face, creating fake truth, and convincing someone.

Interestingly, from forty-nine (49) pairs of conversation, there are nine (9) pairs of non-observed maxims that cannot be revealed in Christoffersen's (2005) categories regarding possible reasons for breaking the maxims. Those numbers of non-observed maxims are Infringing types of non-observance maxims that were classified into other types of possible reasons.

The possible reasons for breaking maxims from the analysis are displayed in Table III.

TABLE III. FREQUENCIES OF IDENTIFIED POSSIBLE REASON IN BREAKING MAXIMS

\begin{tabular}{|c|c|c|c|}
\hline Possible Reason & Occurrences & Percentage & Rank \\
\hline Hiding the truth & 0 & $0 \%$ & - \\
\hline Creating jokes & 0 & $0 \%$ & - \\
\hline Avoiding certain topics & 8 & $16,3 \%$ & 3 \\
\hline $\begin{array}{c}\text { Averting to hurt someone's } \\
\text { feeling }\end{array}$ & 0 & $0 \%$ & - \\
\hline Saving face & 7 & $14,3 \%$ & 4 \\
\hline Creating fake truth & 5 & $10,2 \%$ & 5 \\
\hline Convincing someone & 20 & $40,8 \%$ & 1 \\
\hline Cheering the hearer & 0 & $0 \%$ & - \\
\hline Others & 9 & $18,4 \%$ & 2 \\
\hline Total & 49 & $100 \%$ & - \\
\hline
\end{tabular}

\section{J. Convincing Someone}

The passengers mostly break the maxim for convincing someone. In this case, it is for convincing the customs officer toward their answer or response. In answering the customs officer's question, it was detected that 20 times $(40,8 \%)$ out of 49 pairs of conversation, the passengers were trying to convince the customs officer. For instance, P2 tries to convince the customs officer that a shopping entrusted goods service is not like other shops that sell many items and has an actual shop. This type of reasoning, by adding some additional information, is possibly used by the passenger who wants to strengthen their answer so the hearer can trust the speaker (Christoffersen, 2005). The example is provided below.

\section{O5 : Dijual?}

For sale?

P5 : Engga ini jastip, jadi aku cuma ngambil, gak kayak gimana gimana, cuma gak buka toko.

No, it is a shopping entrusted goods service so I only buy it but do not have a shop.

The example shows that P5 tries to convince O5 how a shopping entrusted goods service works by rejecting the idea of selling items, but actually, it is the same just like an act of selling items. Moreover, P5 emphasizes that there is no actual shop to do this service. P5 also persuades O5 to believe what is P5 said about shopping entrusted goods service.

\section{K. Avoiding Certain Topics}

Some of the passengers' answers were also identified as avoiding certain topics. According to Christoffersen (2005), this type of reason is classified when the speaker tends to answer with a minimal response or also done by giving unrelated answers to change the topic as well. In the case of avoiding certain topics, this type of reason occurred 8 times $(16,3 \%)$ out of 49 pairs of conversation. The following example is shown below.

\section{O2 : Ngisi kertasnya yang biru tadi? \\ Do you fill the blue form? \\ P2 : Gak tau mbak. \\ I don't know.}

The example illustrates $\mathrm{P} 2$ tries to avoid talking about the blue form that usually has to be filled by every passenger who comes from overseas. By answering 'I don't know", it implies that $\mathrm{P} 2$ wants to avoid certain topics from $\mathrm{O} 2$.

\section{Saving Face}

In some pairs of conversation, there are also some passengers' answers that were revealed as saving face where the passengers tried to save their face from embarrassment. This category of reason can be used by the speaker when the speakers have a purpose to cover themselves from awkwardness (Christoffersen, 2005). From the analysis, saving face occurred 7 times $(14,3 \%)$ out of 49 pairs of conversation. The illustration of saving face is revealed below. 
O4 : Mbak nya beli atau dibeliin?

Did someone buy it for you or you buy it?

P4 : Dibeliin lah, enggak mau dibeliin lah kalau kena pajak mah.

Someone buy it for me, I don't want it if get charged.

The following example reveals that $\mathrm{P} 4$ unconsciously mentioned that the shoes were brought by the passenger, while previously $\mathrm{P} 4$ claims the shoes were brought by someone for the passenger. To save the face, $\mathrm{P} 4$ re-claims the answer by saying 'someone buys it for me, I don't want it if get charged'. The passenger's answer is indicated as a reason for saving face because the passenger wants to escape from the embarrassment (Christoffersen, 2005).

\section{Creating Fake Truth}

The passengers also were found to create fake truth when answering the customs officers' questions. From the analysis, it was found 5 times $(10,2 \%)$ out of 49 pairs of conversation. The example below presents the illustration of creating fake truth.

\section{O4 : Kata siapa?}

Who said so?

P4 : Katanya asal jangan baru, kan baru punya ini doang. As long as it was not new, they said. I only have this one.

The illustration above shows $\mathrm{P} 4$ creates something false to be true, $\mathrm{P} 4$ also persuades $\mathrm{O} 4$ to believe it as true information. This happens because $\mathrm{P} 4$ tries to avoid further checking for the shoes that P4 brought from overseas. When P4 said 'As long as it was not new, they said. I only have this one' P4 expects $\mathrm{O} 4$ to believe the information so P4 can hinder paying tax for the shoes. Chistoffersen (2005) claims it is a possible reason to break the maxim by creating a fake truth.

\section{CONCLUSION}

From the analysis and the findings of the study, it can be concluded that the passengers constantly break the maxim of quantity by flouting it. The passengers prefer to flout the maxim of quantity when asked by the customs officer. This has happened because the passengers' answer is followed with additional information or the information itself is less informative.

Moreover, this present study also reveals that the possible reasons for breaking maxims are to convince someone, specifically in convincing the customs officers. By convincing the customs officers, the passengers expect to avoid the process of customs declaration where the passengers have to inform the customs officers about new items that were brought from overseas and if the item exceeds the valid regulation, the passengers have to pay the tax. In other words, the passengers are trying to trick the customs officers to skip the obligation of paying tax. However, the result does not necessarily show that all of the passengers at airports disobey the valid regulation in the country by avoiding pay tax, but to reveal the broken maxim that occurs and the possible reasons for breaking the maxim.

\section{REFERENCES}

Atmajaya, A. O. (2017). Pengaruh terpaan tayangan customs protection di net tv terhadap citra direktorat jenderal bea cukai (Unpublished bachelor's thesis). Universitas Muhammadiyah Surakarta.

Berg, B. L. (2006). Qualitative research methods for the social sciences $\left(6^{\text {th }}\right.$ edn.). Boston: Pearson.

Christoffersen, D. (2005). The shameless liar's guide. Naperville: Sourcebooks Hysteria.

Desilvani, D., Hafiar, H., \& Damayanti, T. (2017). Citra dirjen bea dan cukai pada kasus penyelundupan narkoba dalam tayangan customs protection net tv. ProTVF, 1(2), 105-116. doi: 10.24198/ptvf.v1i2.19870

Grice, H. P. (1975). Logic and conversation. In P. Cole \& J. L. Morgan (Eds.) Syntax and semantics (pp. 41-58). New York: Academic Press.

Herawati, A. (2013). The cooperative principle: Is Grice's theory suitable to Indonesian language culture? Lingua Cultura, 7(1), 43-48. doi: 10.21512/lc.v7i1.417

Virgin, J. A. \& Utami, C. P. (2016). Dominant maxim violations in 'Behind Lawyer Profession' of Hitam Putih talk show. Paper presented at 9th International Conference on Applied Linguistics (CONAPLIN 9). Bandung. 